\title{
THE STRUCTURE AND MECHANICAL PROPERTIES OF DOMEX 700 MC STEEL
}

Nowadays fine-grained, quench and tempered steels are more and more used in design of modern semitrailers constructions. High mechanical properties and durability of this type of steel are its advantage. This paper summarizes the results of research together with the data available by the manufacturer SSAB company. The combination of the special features provided by this material enables construction of lighter semitrailer's components, which would result in a semiauto with a lower weight of its own. This paper presents the results of mechanical properties of Domex 700 MC steel.

Keywords: High strength steels, Domex steel, impact test, impact energy, semitrailers.

\section{Introduction}

Increased competition in the market of semitrailers forces manufacturers to design new solutions and use new materials. Analyzing the products of leading manufacturers of semitrailers including products of Wielton S.A., we observe the tendency to use steel characterized by increased resistance to abrasion of easy weldable steels such as steel Hardox. The materials are also used to apply solutions to reduce the weight of the trailer. All these treatments aim to increase the technical objects lifetime.

Based on research realized by Wielton S.A. we can form a list of requirements for materials used for construction of semitrailers with particular emphasis on the requirements posed by the construction of tippers. Such materials must feature: a very high resistance to abrasion, the ability to transfer variable workloads, uniform properties throughout the cross-section of the element as well as susceptibility to create joints with use of standard welding techniques, and easy cold forming.

\section{Characteristics of Domex steel}

Domex cold forming steels are rolled in a thermomechanical process where the heating, rolling and cooling are carefully controlled. The chemical composition of the steel containing low levels of carbon and manganese is precisely complemented by enriching ingredients such as niobium, titanium and vanadium.

Due to its high mechanical properties and clean structure, the Domex steel is the best alternative for cold formed and welded products. Domex $700 \mathrm{MC}$ steel with designation D and E meet and even exceed the requirements for steel S700 MC according to the standard EN-10149-2 [1]. Domex MC steel can be supplied as wide coil, split coil and cut sheet. The steels are applicable with rolled and pickled as well as oiled surface. Wide coil and sheet are available with milled or cut edge.

Extra high strength steels are used in structures such as truck chassis, cranes and excavators. In these applications, high strength steel is used in order to reduce weight while simultaneously increase load capacity of the structure. These advantages, combined with good formability allow the reduction of total costs. Due to the low content of carbon, phosphorus and sulfur Domex $700 \mathrm{MC}$ steel can be welded by all commonly used methods without requirement of preheating. A narrow heataffected zone is formed on the border of the weld. This zone is characterized by slightly lower hardness. However, using the normal parameters and methods of welding this zone is of no practical importance. Tested specimens taken across the weld can have the same minimum value of tensile strength, which also characterizes the welded material. If the load of the weld is not high, it can be used to add metal with a lower strength than the weld material. There are a large number of filler metals with the same or higher strength, which can be used for welding of Domex $700 \mathrm{MC}$ steel, while maintaining the same filler metal strength as welded material [2 and 3].

Advantages of using Domex steel:

- reduced weight of steel construction while maintaining loading capacity,

- very good weldability due to low alloy content; resistance to hot and hydrogen cracks,

- good bendability at small radii without risk of cracks,

- good formability facilitating press-forming,

- applicable for shear cutting and plasma cutting.

- smooth and straight edges after laser.

\footnotetext{
* Magdalena Mazur ${ }^{1}$, Robert Ulewicz ${ }^{1}$, Frantisek Novy $^{2}$, Pawel Szataniak ${ }^{3}$

${ }^{1}$ Institute of Production Engineering, Czestochowa University of Technology, Poland

${ }^{2}$ Department of Materials Engineering, University of Zilina, Slovakia

${ }^{3}$ WIELTON S.A., Wielun, Poland

E-mail: mazur.m@zim.pcz.pl
} 


\begin{tabular}{|c|c|c|c|c|c|c|c|c|}
\hline \multicolumn{8}{|c|}{ Chemical composition max. [in weight \%] } \\
\hline $\mathrm{C}$ & $\mathrm{Si}$ & $\mathrm{Mn}$ & $\mathrm{P}$ & $\mathrm{S}$ & $\mathrm{Al}$ & $\mathrm{Nb}$ & $\mathrm{V}$ & $\mathrm{Ti}$ \\
\hline 0.12 & 0.10 & 2.10 & 0.025 & 0.010 & 0.015 & 0.09 & 0.20 & 0.015 \\
\hline \multicolumn{3}{|c|}{ Mechanical properties } \\
\hline \\
\hline \multicolumn{3}{|c|}{$\mathrm{Rm}[\mathrm{MPa}]$} & \multicolumn{3}{c|}{$\mathrm{A}[\%]$} \\
\hline
\end{tabular}
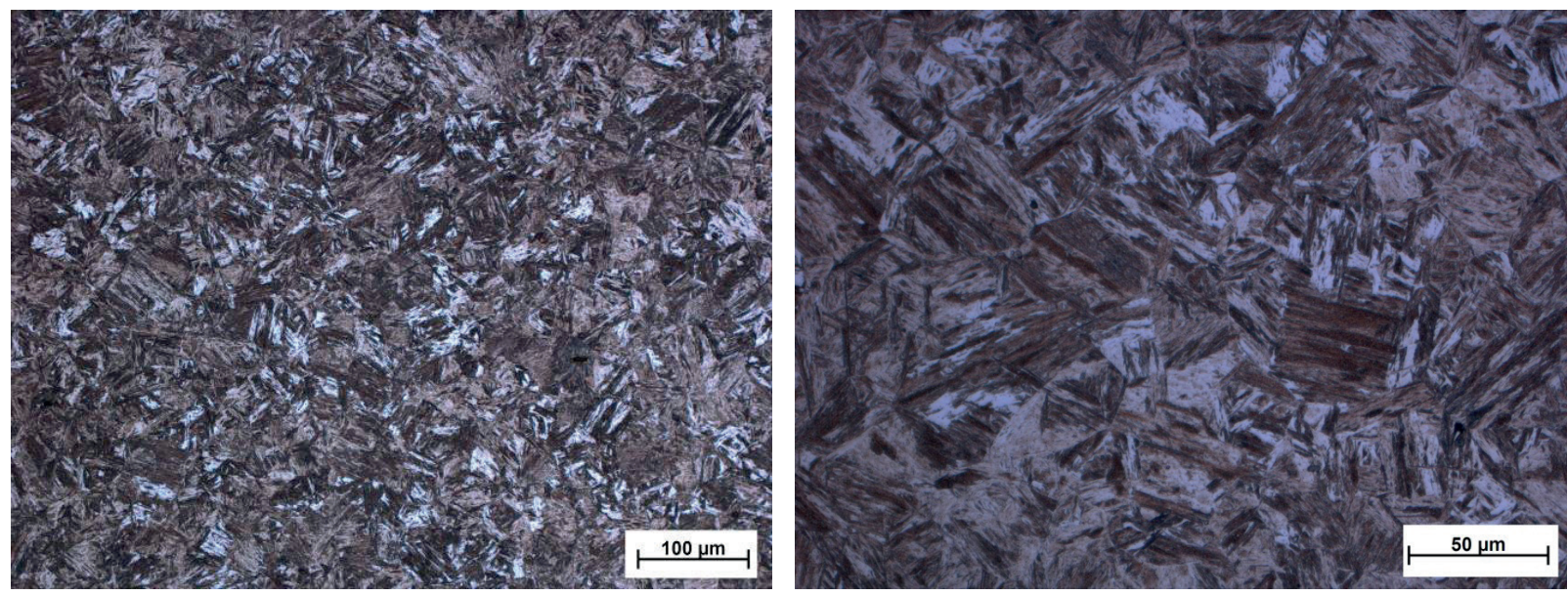

Fig. 1 Microstructure of the Domex 700 MC steel

Domex corrosion resistant steel can be used in products as e.g. containers where high strength and resistance to corrosion reduces the need for maintenance, prolongs life and simplifies production. The material also offers major benefits for industrial chimneys, both externally and in the flue gas passages, since the corrosionresistant steels can cope well with sulphurous environments. In addition to good resistance to corrosion, Domex corrosion resistant steel is also characterized by good formability, weldability and impact strength. It is produced in two strength levels and the guaranteed minimum yield strengths are $550 \mathrm{MPa}$ and $700 \mathrm{MPa}$.

\section{Mechanical properties of Domex $700 \mathrm{MC}$ steel}

Domex is a micro-alloy steel with addition of niobium, titanium and vanadium, which allows for maintaining low level of carbon and manganese content. Advanced technological production processes guarantee the steels' clean structure (Fig. 1). The tested steel had a martensitic structure, with clear needles arranged in cells [4 and 5]. Table 1 shows the chemical composition and mechanical properties of Domex $700 \mathrm{MC}$ steel.

\section{Impact test of Domex $700 \mathrm{MC}$ steel}

Construction elements are very often exposed to dynamic loads. For this reason, there is a need to know the properties that characterize the behavior of the material in case of sudden changes in load. Mainly fatigue and impact tests are used to determining these properties. Impact tests allow exploring the impact toughness and, at the same time, they allow checking the quality of heat treatment, in regard to tendency of the material to aging and defining the resistance against to the brittle fracture. In practice, the most common is the Charpy impact test [6 and 7].

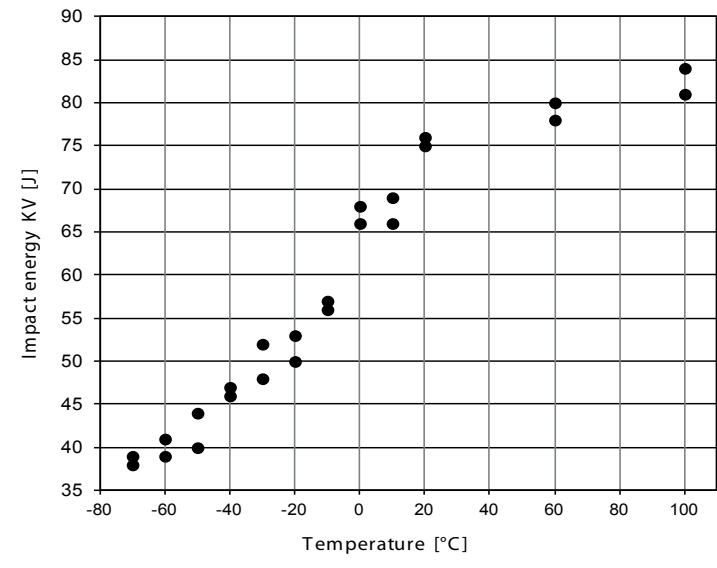

Fig. 2 Impact energy $\mathrm{v} / \mathrm{s}$ temperature for Domex 700 MC steel 

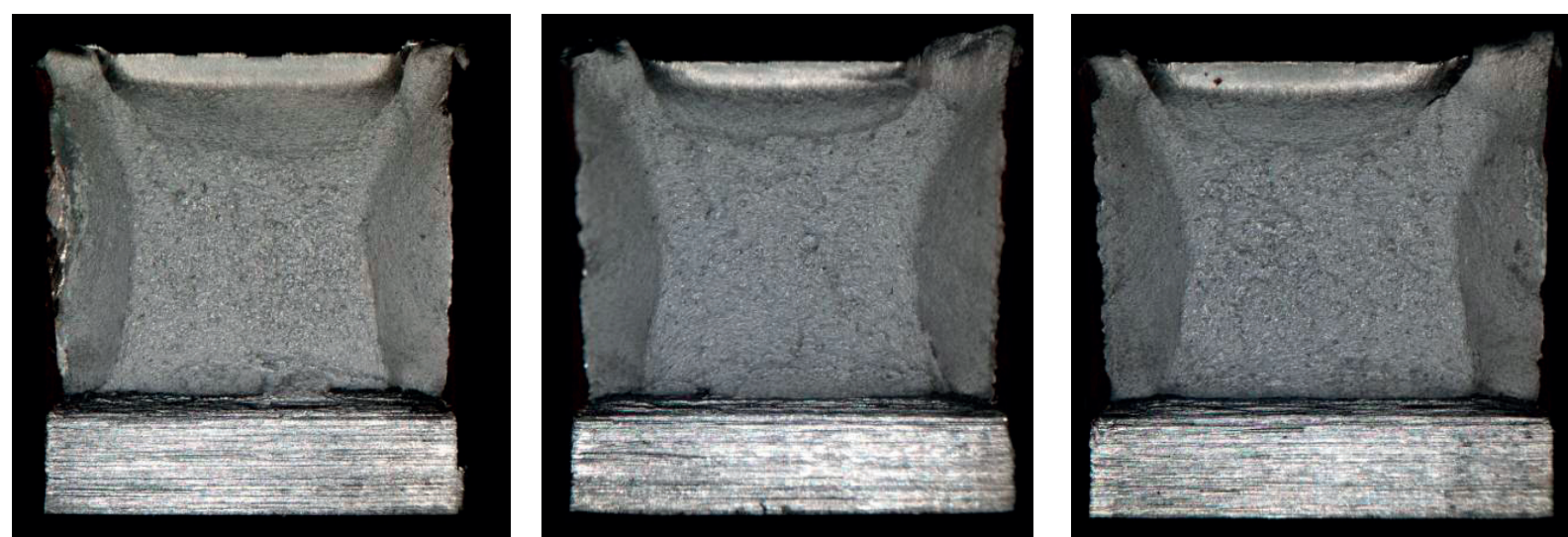

a)

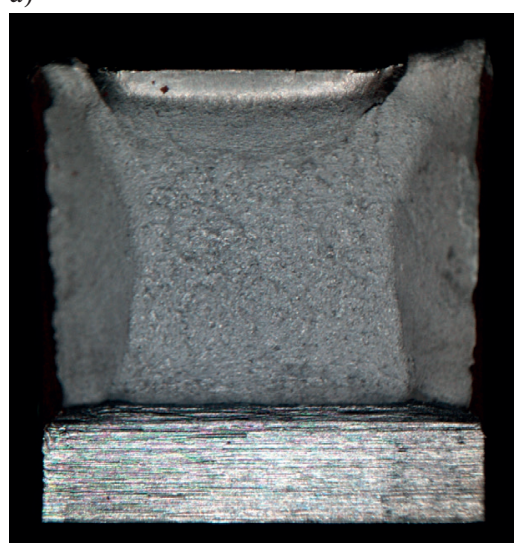

d)

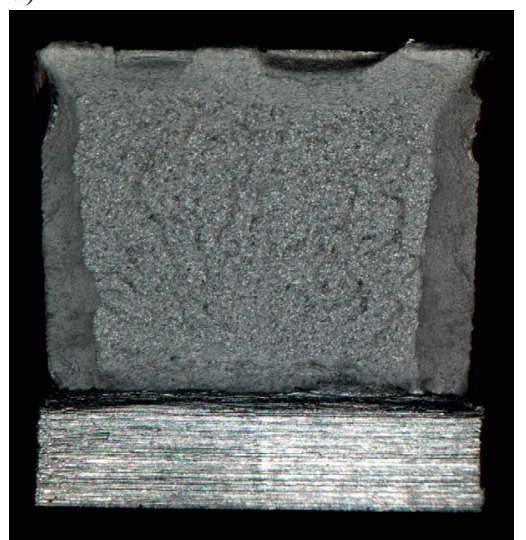

g) b)

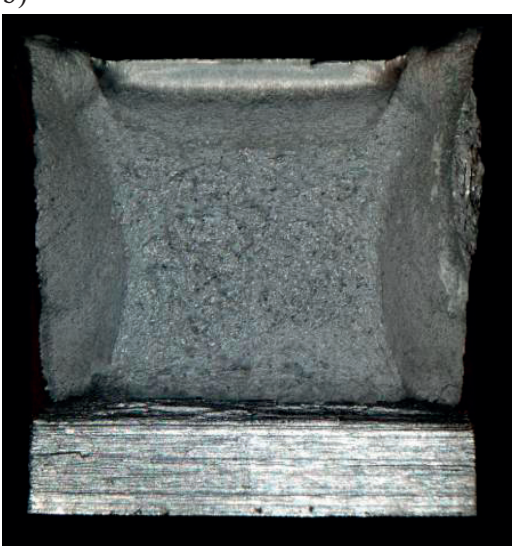

e)

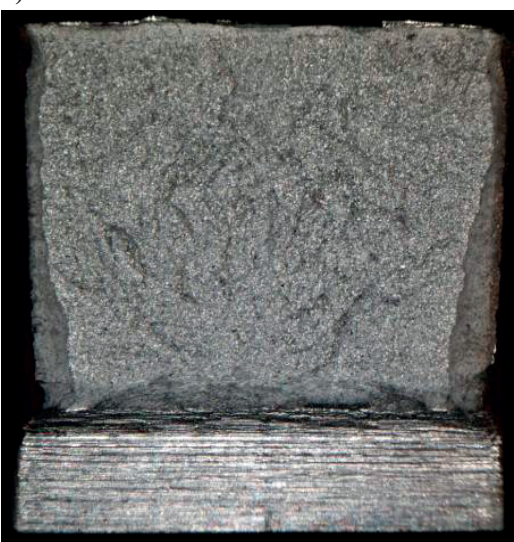

h) c)

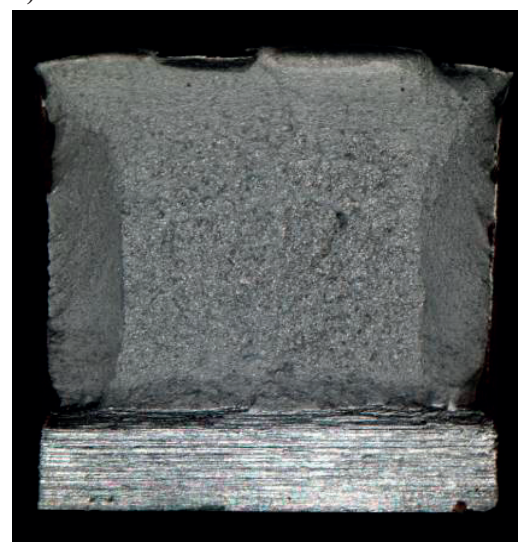

f)

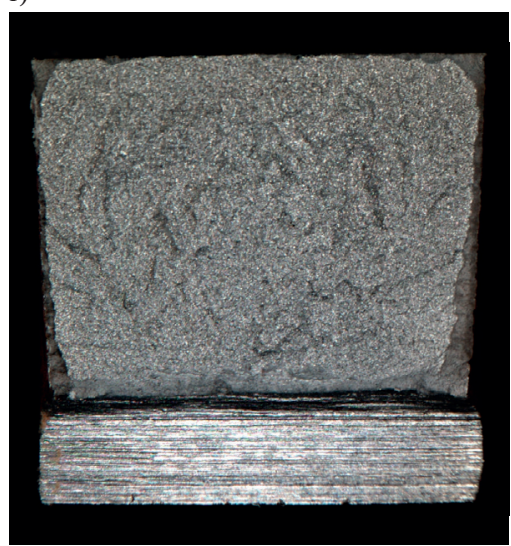

i)

Fig. 3 Fracture morphology of the specimens broken at temperature: a) $+100^{\circ} \mathrm{C}$, b) $\left.\left.\left.+20^{\circ} \mathrm{C}, \mathrm{c}\right)+15^{\circ} \mathrm{C}, \mathrm{d}\right)+10^{\circ} \mathrm{C}, e\right) 0^{\circ} \mathrm{C}$, f) $\left.-10^{\circ} \mathrm{C}, \mathrm{g}\right)-30^{\circ} \mathrm{C}$, h) $-50^{\circ} \mathrm{C}$, i) $-70^{\circ} \mathrm{C}$

Impact tests were performed in order to assess behavior of the material under conditions leading to brittle fracture. Semitrailers are commonly working in a wide temperature range. In general, lower temperature increases the material tendency to brittle fracture and this is the reason why impact test were performed in temperature range from $-70{ }^{\circ} \mathrm{C}$ up to $+100{ }^{\circ} \mathrm{C}$ with use of 24 specimens. For testing at different temperatures, the specimens were immersed in a cooling medium or heated in the oven for a time necessary to obtain required temperature in the whole volume of the specimen. Standard specimens for Charpy impact test (a length of $55 \mathrm{~mm}$ and a square cross-section of $10 \mathrm{~mm}$ side length) were used. In the centre of specimens was made a V-shaped notch, with an angle of $45^{\circ}$, a depth of $2 \mathrm{~mm}$ and the rounding radius of the bottom of $0.25 \mathrm{~mm}$. The impact tests were done using the Standard Charpy impact equipment, swinging with 
a constant energy resource potential. The results obtained during the experiment are shown in Fig. 2.

\section{Summary}

The determination of the temperature effect on material properties, mainly the tendency to brittle fracture at low temperatures is very important for safety design of components working at temperatures below $0{ }^{\circ} \mathrm{C}$. Impact tests greatly reflect the material behavior under different temperatures and after systematic analysis it is possible to find the threshold, where material rapidly loses its ductility. The results obtained for Domex $700 \mathrm{MC}$ steel show that the impact energy $\mathrm{KV}=75 \mathrm{~J}$ obtained at the temperature of $20{ }^{\circ} \mathrm{C}$ drops down to $\mathrm{KV}=38 \mathrm{~J}$ at the temperature of $-70{ }^{\circ} \mathrm{C}$. Comparing the obtained results with the material data specified by the manufacturer can be said that in the temperature range from $-20{ }^{\circ} \mathrm{C}$ to $-40{ }^{\circ} \mathrm{C}$ were obtained higher values of impact energy than are listed in the material datasheet. Based on the fracture morphology (Fig. 3) it can be observed that with decreasing temperature, the fracture mechanism changes from ductile to quasi cleavage manner [8]. As the temperature decreases, the ratio between the ductile and brittle fracture changes and bigger part of the fracture surface is formed by brittle fracture.

Increase of production and optimization of operating costs is the main interest of every manufacturer. This is why they pay great attention to obtain the highest level of components durability and safety. In the search for new design solutions, there is a great requirement for new materials with higher mechanical properties than the conventional ones [9 and 10]. Later in research, the obtained steel characteristics will be the basis for determination of other material properties and specification of components which can be produced from this steel in WIELTON S.A semitrailers [11].

\section{Acknowledgement}

This research was supported by the grant program „DoktoRIS - Scholarship program for innovative Silesia" co-financed by the European Union under the European Social Fund and partially by the Scientific Grant Agency of the Ministry of Education, Science and Sports of the Slovak Republic and Slovak Academy of Sciences, grant No. 1/0743/12 and by APVV, project SK-RO00088-12.

\section{References}

[1] WIELTON, S. A.: Company Information Data (in Polish), Wielun 2011.

[2] MAZUR M., ULEWICZ, R., BORKOWSKI, S., NOVY F. Properties of Steel Used in the Production of Semi-Trailers Car. W: SEMDOK 2012. 17th Intern. of PhD. Students`Seminar, 2012, Zilina - Terchova, 2012.

[3] SZATANIAK P., ULEWICZ, R., NOVY, F., MAZUR M., TOROKOVA, A.: New Materials and Requirements for Construction Materials Applied to Car Semitrailers. W: Advanced Manufacturing and Repair Technologies in Vehicle Industry, 29th Intern. Colloquium, Zilina - Terchova, Slovakia. EDIS - University of Zilina, 2012

[4] TILlOVA, E., CHALUPOVA, M.: Solution Treatment Effect on Microstructure and Mechanical Properties of Automotive Cast Alloy. Materials Engineering/Materialove inzinierstvo, vol. 19, No. 2, 2012, pp. 39-46.

[5] MIKOVA, K., NOVY, F., TRSKO, L., BOKUVKA O.: Fatigue Life of Micro-alloyed Steels for Pipelines Intended to Transport Natural Gas (in Slovak), SEMDOK 2012, 17th Intern. of PhD. Students' Seminar, Zilina - Terchova, pp. 193-196, EDIS - University of Zilina, 2012.

[6] WYRZYKOWSKI, J. W., PLESZAKOW, E., SIENIAWSKI, J.: Deformation and Cracking of Metal (in Polish). Wydawnictwo Naukowo-Techniczne, 1999.

[7] SKOCOVSKY, P., BOKUVKA, O., KONECNA, R., TILLOVA, E.: Theory of Materials Science for Departments of Mechanical Engineering (in Slovak), EDIS - University of Zilina, 2001.

[8] ZEMANDL, M.: Fractography of Fatigue Fracture and its Practical Use in the Analysis of the Causes Machine Elements Failure (in Czech), Summer school of fatigue '2006, EDIS - University of Zilina, 2006.

[9] KONSTANCIAK, M.: Analysis of Technological Strategies on the Example of the Production of the Tramway Wheels, Archives of Materials Science and Engineering, No. 2, vol. 57, 2012, pp. 69-74.

[10] DIMA, I. C., GRZYBOWSKI, A., GRABARA, J.: Statistical Modeling of the Mechanical Properties of the Heavy Steel Plates Dealing with the Ill Conditioned Data. Metalurgia International, No. 1, vol. 18, pp. 11-14, ISSN: 1582-2214

[11] ULEWICZ, R., MAZUR, M., NOVY, F., SZATANIAK, P. Fatigue Properties of Selected Grades of Steel Used for Main Components of Semitrailers and Agricultural Machines. W: Advanced Manufacturing and Repair Technologies in Vehicle Industry, 29th Intern. Colloquium, 2012, Zilina - Terchova, pp. 64-70, EDIS - University of Zilina, 2012. 